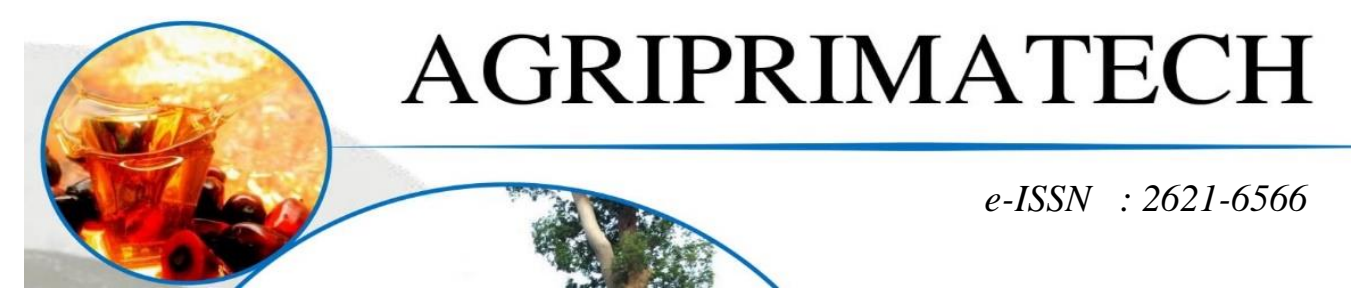

\title{
PERSEPSI PETANI TERHADAP BENIH KELAPA SAWIT BERSERTIFIKAT DAN NONBERSERTIFIKAT
}

\author{
LAURA JUITA PINEM ${ }^{1}$ \\ ${ }^{1}$ Fakultas Agro Teknologi, Universitas Prima Indonesia \\ E-mail : laurajuita.pinem@gmail.com
}

\begin{abstract}
Abstrak
Penelitian ini bertujuan untuk menganalisis persepsi petani terhadap benih kelapa sawit bersertifikat dan non sertifikat, menganalisis tahapan proses pengambilan keputusan pembelian petani dalam memilih benih bersertifikat dan non sertifikat, dan menganalisis faktor-faktor yang mempengaruhi proses pengambilan keputusan pembelian petani dalam memilih benih kelapa sawit bersertifikat dan non sertifikat di Kabupaten Labuhan Batu Utara.

Penelitian ini dianalisis dengan bantuan 100 responden. Analisis persepsi dilakukan dengan menggunakan teknik scoring dan dianalisis dengan menggunakan rata-rata skor dan perceptual mapping dengan grafik jaring laba-laba. Nilai rata-rata total persepsi petani terhadap benih kelapa sawit bersertifikat adalah 3,55 dan masuk kedalam kategori baik sedangkan untuk benih kelapa sawit nonsertifikat skor rata-rata total persepsi petani ada;ah 2,34 dan termasuk kategori kurang baik
\end{abstract}

Kata kunci: Benih, Kelapa Sawit, Persepsi, Petani, Bersertifikat

\section{Pendahuluan}

Benih merupakan salah satu faktor penentu produksi tanaman selain dari dukungan faktor-faktor produksi lainnya seperti pupuk, air, cahaya, dan iklim. Benih yang bermutu rendah walaupun didukung oleh faktor-faktor produksi lainnya yang cukup maka hasilnya akan rendah karena mutu benih mencakup mutu genetis, mutu fisiologis, dan mutu fisik. Mutu genetis menunjukkan identitas genetis dari tanaman induknya sedangkan mutu fisiologis merupakan kemampuan daya hidup (viabilitas) benih yang mencakup daya kecambah dan kekuatan tumbuh benih. Sedangkan mutu fisik menunjukkan penampilan benih seperti ukuran homogen, bernas, bersih dari campuran, bebas hama dan penyakit, dan kemasan menarik. Penggunaan benih yang tidak tepat di Kabupaten Labuhan Batu Utara merupakan satu penyebab produktifitas kelapa sawit yang dikelola oleh petani tidak menghasilkan produktifitas yang maksimal. Penggunaan benih dengan kualitas yang rendah bisa menyebabkan petani merugi dalam kurun waktu yang panjang karena kelapa sawit merupakan tanaman tahunan. Sodikin (2015) mengatakan bahwa terdapat perbedaan produksi antara usahatani padi bersertifikat dan usahatani padi non sertifikat di Desa Sidomukti. Petani mempunyai persepsi yang beragam terhadap benih yang mereka pakai. 
Persepsi yang terbentuk dalam diri petani pada akhirnya berpengaruh terhadap cara pandang petani terhadap keunggulan dan kelemahan benih kelapa sawit bersertifikat dan non sertifikat. Persepsi ini jugalah yang akan menjadi salah satu pendorong atau penghambat petani menggunakan benih bersertifikat atau non sertifikat. Persepsi berperan penting terhadap pengambilan keputusan petani dalam membeli benih bersertifikat dan non sertifikat.

Berdasarkan alasan tersebut, maka dapat dirumuskan beberapa pertanyaan yang menjadi dasar penelitian ini :

1. Bagaimanakah persepsi petani kelapa sawit terhadap benih bersertifikat dan non sertifikat di Kabupaten Labuhan Batu Utara?

\section{Metode}

Penelitian dilaksanakan di Kabupaten Labuhan Batu Utara, Sumatera Utara. Lokasi ditetapkan sebagai tempat

- Pernyataan positif

1) Sangat Setuju (SS)

2) Setuju (S)

3) Netral $(\mathrm{N})$

4) Tidak Setuju(TS)

5) Sangat Tidak Setuju

- Pernyataan negatif

1) Sangat Setuju (SS)

2) Setuju (S)

3) Netral $(\mathrm{N})$

4) Tidak Setuju(TS)

5) Sangat Tidak Setuju

Menurut Ridwan (2010), penentuan rata-rata skor dari setiap pernyataan dan penelitian secara purposive dengan pertimbangan bahwa Kabupaten Labuhan Utara merupakan salah satu kabupaten yang memiliki potensi untuk pengembangan komoditas kelapa sawit di Sumatera Utara dan selain itu terdapat terdapat banyak petani rakyat yang menggantungkan hidup pada komoditas kelapa sawit di Kabupaten Labuhan Batu Utara. Penelitian dilakukan pada tahun 2020.

Analisis persepsi dilakukan dengan menggunakan data kualitatif yang dikuantitatifkan dengan teknik scoring dan dianalisis dengan menggunakan metode rata-rata skor. Persepsi petani merupakan penilaian petani dengan menggunakan 6 indikator (Tabel 2). Persepsi petani diukur dengan menggunakan pernyataanpernyataan positif dan negatif yang menjadi indikator persepsi petani dalam penggunaan benih. Jawaban dari pernyataan diukur dengan skala likert dengan skor yang telah ditentukan sebagai berikut :

$$
\begin{aligned}
& \text { : skor } 5 \\
& \text { : skor } 4 \\
& \text { : skor } 3 \\
& \text { : skor } 2 \\
& \text { : skor } 1
\end{aligned}
$$

: skor 1

: skor 2

: skor 3

: skor 4

: skor 5

interval kelas didapat dengan menggunakan rumus :

$$
\begin{gathered}
\text { Rata }- \text { rata skor }=\frac{\text { Total skor }}{\text { Jumlah Responden }} \\
\text { Interval kelas }=\frac{\text { Nilai tertinggi }- \text { Nilai terendah }}{\text { Jumlah kelas interval }}
\end{gathered}
$$

Maka berdasarkan rumus di atas, panjang interval kelas adalah

$$
\text { Interval kelas }=\frac{5-1}{5}=0,8
$$


Persepsi petani terhadap benih kelapa sawit bersertifikat dan non sertifikat dikategorikan dalam 5 kelas, yaitu :

$1.00-1.80$ : Sangat tidak baik

$1.81-2.60$ : Tidak baik

$2.61-3.40$ : Kurang baik

$3.41-4.20$ : Baik

$4.21-5.00$ : Sangat baik

Persepsi petani terhadap benih kemudian dipetakan dengan menggunakan teknik pemetaan persepsi konsumen (perceptual mapping). Pengolahan data dillakukan dengan bantuan software MS-Excel. Perceptual mapping yang akan dilakukan pada Tabel 1. Indikator dan atribut penentuan penggunaan benih bersertifikat dan non sertifikat penelitian meliputi 3 bagian : (1) peta persepsi petani pengguna benih bersertifikat dan non sertifikat; (2) peta persepsi petani pengguna benih bersertifikat dan non sertifikat; dan (3) peta persepsi petani terhadap benih bersertifikat dan non sertifikat.

\begin{tabular}{|c|c|c|}
\hline No & Indikator & Atribut \\
\hline 1 & Tepat waktu & $\begin{array}{ll}\text { - } & \text { Ketersediaan benih } \\
\text { - } & \text { Umur panen }\end{array}$ \\
\hline 2 & Tepat jumlah & $\begin{array}{ll}\text { - } & \text { Jumlah ketersediaan benih } \\
\text { - } & \text { Kesesuaian ketersediaan benih dengan } \\
\text { kebutuhan }\end{array}$ \\
\hline 3 & Tepat lokasi & $\begin{array}{ll}\text { - Kesesuaian dengan kondisi } \\
\text { daerah }\end{array}$ \\
\hline 4 & $\begin{array}{l}\text { Tepat } \\
\text { jenis/varietas }\end{array}$ & $\begin{array}{ll}\text { - } & \text { Kesesuaian dengan kebutuhan dan kebiasaan } \\
& \text { kemudahan mendapatkan benih } \\
\text { - } & \text { Kemudahan dalam penggunaan/pemeliharaan } \\
\text { - } & \text { Ketahanan terhadap hama dan penyakit tanaman }\end{array}$ \\
\hline 5 & Tepat mutu & $\begin{array}{ll}- & \text { Daya tumbuh benih } \\
- & \text { Daya simpan benih } \\
- & \text { Produktivitas } \\
- & \text { Kualitas } \\
\end{array}$ \\
\hline 6 & Tepat harga & - Harga benih \\
\hline
\end{tabular}

Hasil dan Pembahasan,

Persepsi Petani terhadap Benih Bersertifikat $\begin{array}{lr}\text { Persepsi merupakan proses } & \begin{array}{r}\text { menan } \\ \text { memilih, }\end{array} \text { mengatur, } \\ \text { menginterpretasikan informasi dari dunia }\end{array}$ sekitarnya. Respon dari kelima panca indera merupakan penerima dari informasi sehingga penerima bisa memberi respon baik buruk atau positif negatifnya hal tersebut (Salomon et al,2006). Petani pada penelitian merupakan individu yang membeli barang atau jasa untuk memenuhi kebutuhannya akan benih. Persepsi petani terhadap penggunaan benih kelapa sawit bersertifikat dalam penelitian ini meliputi 6 macam indikator, yaitu : 1) tepat waktu, 2) tepat jumlah, 3) tepat lokasi, 4) tepat jenis/varietas, 5) tepat mutu, dan 6) tepat harga. Dari keenam indikator tersebut dijabarkan lagi menjadi 14 atribut. Persepsi Petani terhadap benih bersertifikat dapat dilihat pada Gambar 1.

a. Tepat Waktu

Terdapat dua indikator dalam menentukan indikator tepat 
waktu, yaitu ketersediaan benih pada saat dibutuhkan dan umur panen. Skor ketersediaan benih menurut petani benih nonsertifikat adalah 3,06. Skor ini menunjukkan hasil yang kurang baik terhadap ketersediaan benih pada saat dibutuhkan oleh petani. Hal ini disebabkan oleh kurangnya informasi yang diperoleh oleh petani benih nonsertifikat mengenai penyedia benih bersertifikat.

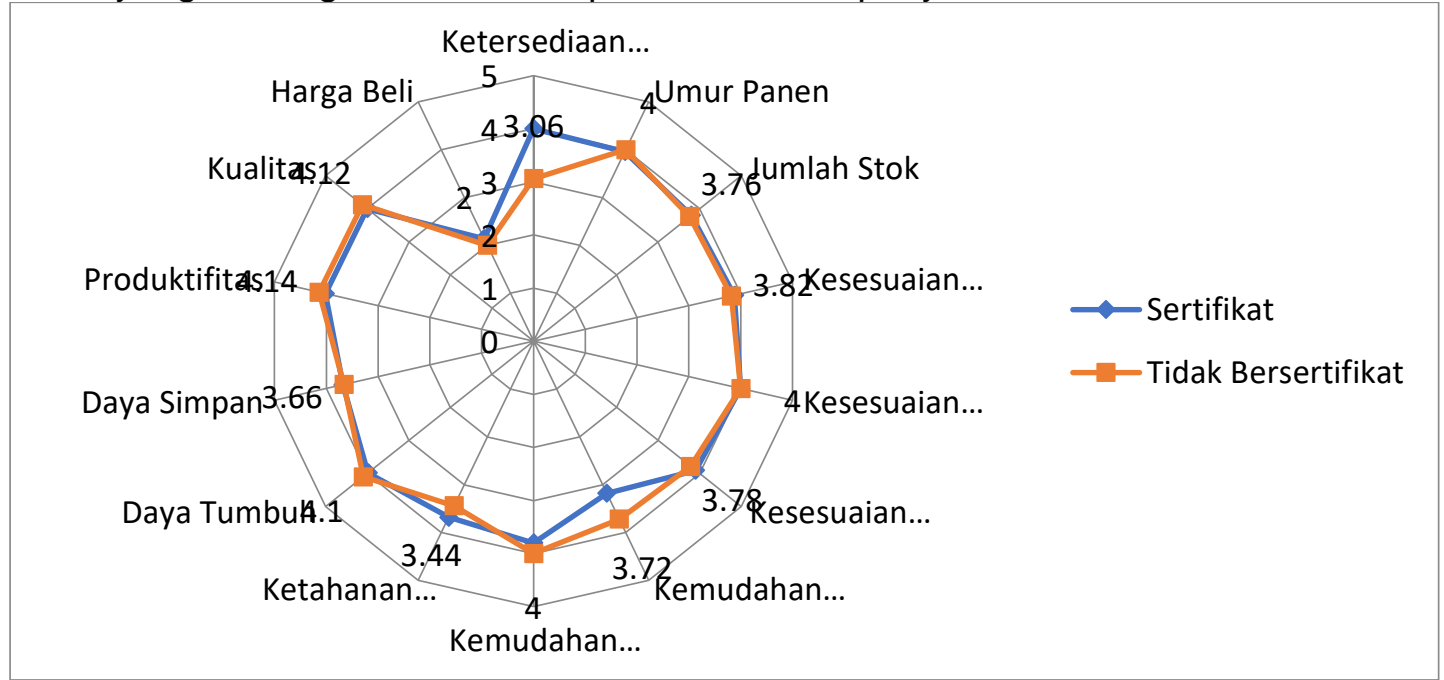

Gambar 1. Peta Persepsi Petani Terhadap Benih Kelapa Sawit Bersertifikat

Skor indikator umur panen dari tanaman yang menggunakan benih bersertifikat merupakan indikator kedua dari indikator tepat waktu. Skor petani pengguna benih bersertifikat dan nonsertifikat masing-masing adalah 3,94 dan 4. Skor ini menunjukkan bahwa persepsi petani terhadap benih bersertifikat berdasarkan indikator umur panen adalah baik. Hal ini menginterpretasikan bahwa benih bersertifikat dipersepsikan oleh petani sebagai benih yang mempunyai umur panen tepat waktu atau bahkan lebih cepat.

Rata-rata total skor masingmasing kelompok petani pengguna benih sertifikat dan nonsertifikat dengan indikator tepat waktu adalah 3,98 dan 3,52. Skor ini menunjukkan bahwa secara keseluruhan petani mempunyai persepsi bahwa benih kelapa sawit bersertifikat adalah baik berdasarkan indikator tepat waktu.

b. Tepat Jumlah
Indikator tepat jumlah dibagi menjadi 2 indikator, yaitu jumlah ketersediaan benih dan kesesuaian ketersediaan benih dengan kebutuhan. Berdasarkan Gambar 1 ketersediaan benih kelapa sawit bersertifikat cukup banyak, hal ini ditunjukkan oleh skor yang ditunjukkan oleh masing-masing petani pengguna benih bersertifikat dan non sertifikat yaitu 3,8 dan 3,76 . Sedangkan berdasarkan kesesuaian ketersediaan benih dengan kebutuhan hasil yang ditunjukkan oleh Gambar 8 mengintrepretasikan bahwa ketersediaan benih bersertifikat dapat memenuhi kebutuhan benih petani kelapa sawit dengan masing-masing skor 3,88 dan 3,82.

c. Tepat Lokasi

ditunjukkan Indikator tepat lokasi kesesuaian dengan kondisi agroekosistem daerah setempat. Petani akan menggunakan benih kelapa sawit bersertifikat bila benih yang digunakan sesuai dengan agroekosistem lahan yang dimiliki oleh petani. Skor yang ditunjukkan oleh petani untuk indokator 
kesesuaian dengan kondisi agroekosistem lahan petani samasama menunjukkan skor 4 , hal ini menggambarkan bahwa benih kelapa sawit bersertifikat sesuai atau baik ditanam dilahan mereka.

d. Tepat Jenis/Varietas

Indikator tepat jenis/varietas dianalisis berdasarkan empat jenis indikator, yaitu kesesuaian benih dengan kebutuhan dan kebiasaan petani, kemudahan mendapatkan benih, kemudahan dalam penggunaan/perawatan benih, dan ketahanan terhadap hama dan penyakit tanaman.

Total skor indikator tepat jenis/varietas yang ditunjukkan oleh kedua kelompok petani adalah baik. Masing-masing skor yang dihasilkan oleh kedua kelompok tersebut adalah 3,64 untuk total skor petani pengguna benih bersertifikat dan 3,74 untuk skor petani pengguna benih nonsertifikat.

e. Tepat Mutu

Indikator tepat mutu pada penelitian ini dibagi menjadi empat bagian, yaitu daya tumbuh benih, daya simpan benih, produktivitas benih, dan kualitas benih. Petani akan menggunakan benih kelapa sawit bersertifikat apabila daya tumbuhnya baik, daya simpannya lama, produktivitasnya tinggi, dan kualitasnya baik.

Total skor yang dihasilkan oleh indikator tepat mutu dari kedua kelompok petani adalah 3,92 untuk petani pengguna benih bersertifikat dan 4,01 untuk petani pengguna benih nonsertifikat. Kedua total skor yang ditunjukkan menunjukkan bahwa benih kelapa sawit bersertifikat berdasarkan indikator tepat mutu adalah baik.

f. Tepat Harga

Indikator tepat harga ditentukan berdasarkan harga benih kelapa sawit bersertifikat. Gambar 2 menunjukkan skor masing-masing kelompok petani kelapa sawit, skor petani kelapa sawit bersertifikat adalah 2,14 dan skor petani nonsertifikat adalah 2,14. Skor yang ditunjukkan oleh Gambar 2 menunjukkan bahwa harga benih kelapa sawit bersertifikat yang ditawarkan kepada petani tidak baik dengan kata lain harga benih kelapa sawit bersertifikat dapat digolongkan mahal bagi petani.

Tabel 2 menunjukkan bahwa skor rata-rata persepsi petani benih bersertifkat terhadap benih kelapa sawit bersertifikat adalah 3,59 dan skor rata-rata persepsi petani benih nonsertifikat terhadap benih kelapa sawit bersertifikat adalah 3,51. Skor rata-rata tersebut menunjukkan bahwa persepsi petani terhadap benih kelapa sawit bersertifikat tergolong baik. Walaupun terdapat beberapa atribut yang menjadi faktor penghambat petani dalam menggunakan benih kelapa sawit bersertifikat diantaranya : (1) Faktor penghambat pengunaaan benih kelapa sawit bersertifikat oleh petani benih bersertifikat adalah atribut harga yang tergolong mahal bagi petani dan (2) Faktor penghambat penggunaan benih kelapa sawit bersertifikat oleh petani benih nonsertifikat adalah ketersediaan benih dan harga yang tergolong mahal bagi petani.

Tabel 2. Persepsi Petani Terhadap Benih Kelapa Sawit Bersertifikat

\begin{tabular}{clcccc}
\hline \multirow{2}{*}{ No } & Variabel & \multicolumn{2}{c}{ Petani Benih Bersertifikat } & \multicolumn{2}{c}{ Petani Benih Nonsertifikat } \\
\cline { 3 - 6 } & & Skor & Kategori & Skor & Kategori \\
\hline 1 & Tepat Waktu & 3,98 & Baik & 3,53 & Baik \\
2 & Tepat Jumlah & 3,84 & Baik & 3,79 & Baik \\
3 & Tepat Lokasi & 4 & Baik & 4 & Baik \\
4 & Tepat Jenis/Varietas & 3,64 & Baik & 3,74 & Baik
\end{tabular}


Agriprimatech

Vol. 4 No. 2, April 2021

e-ISSN : 2621-6566

\begin{tabular}{llcccc}
5 & Tepat Mutu & 3,92 & Baik & 4,01 & Baik \\
6 & Tepat Harga & 2,14 & Tidak baik & 2 & Tidak baik \\
& Total & $\mathbf{3 , 5 9}$ & Baik & $\mathbf{3 , 5 1}$ & Baik \\
\hline
\end{tabular}

Persepsi Petani Terhadap Benih Kelapa Sawit Nonsertifikat

Persepsi petani terhadap
penggunaan benih kelapa sawit
nonsertifikat dalam penelitian ini meliputi 6
macam indikator, yaitu : 1) tepat waktu, 2)
tepat jumlah, 3) tepat lokasi, 4) tepat
jenis/varietas, 5) tepat mutu, dan 6) tepat

harga. Dari keenam indikator tersebut dijabarkan lagi menjadi 14 atribut. Persepsi petani pengguna benih bersertifikat dan nonsertifikat terhadap benih kelapa sawit nonsertifikat digunakan perceptual mapping. Persepsi Petani terhadap benih bersertifikat dapat dilihat pada Gambar 2.

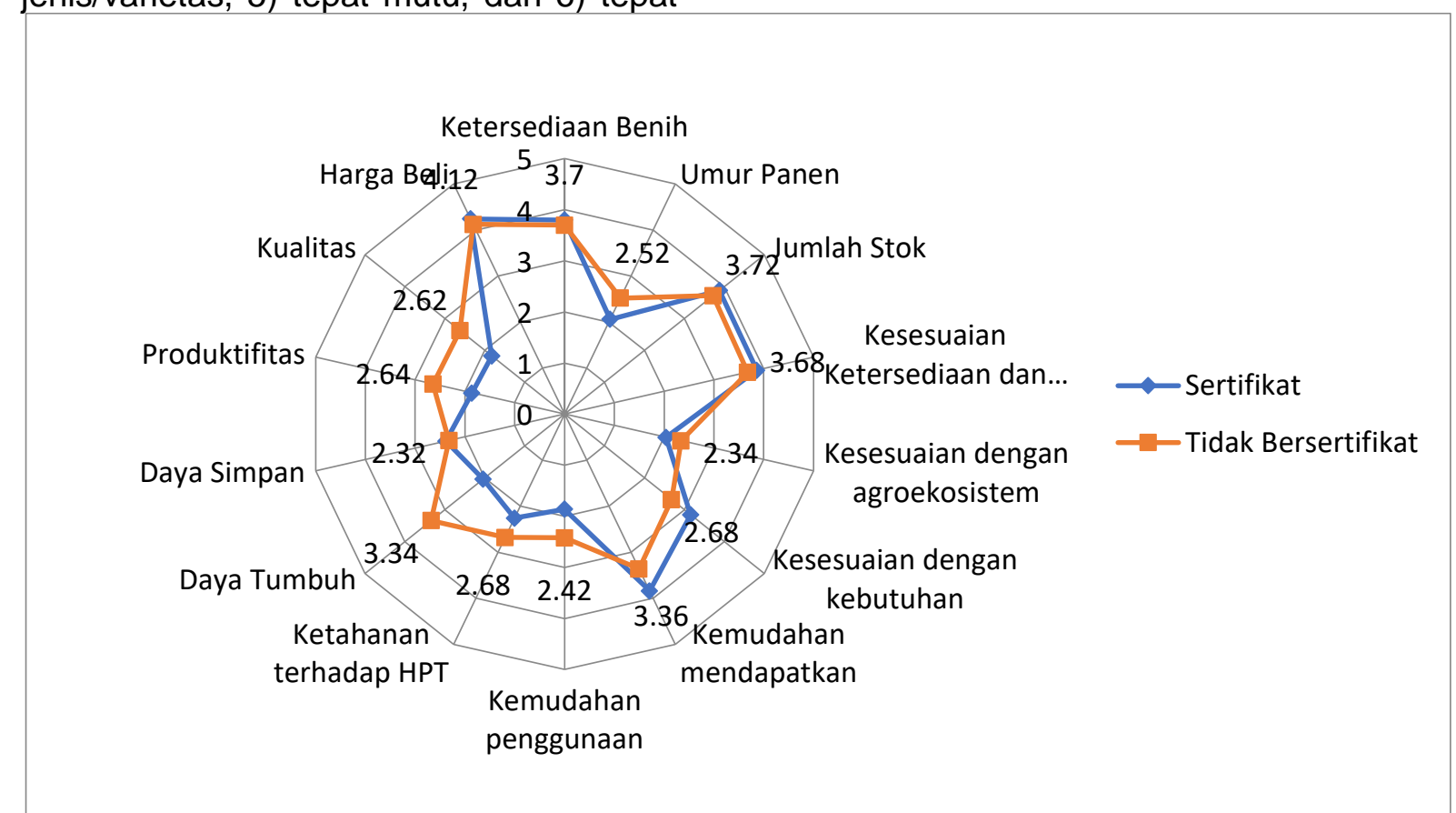

Gambar 2. Peta Persepsi Petani Terhadap Benih Kelapa Sawit Nonsertifikat

a. Tepat Waktu

Terdapat dua indikator dalam menentukan indikator tepat waktu, yaitu ketersediaan benih pada saat dibutuhkan dan umur panen. Rata-rata total skor masingmasing kelompok petani pengguna benih sertifikat dan nonsertifikat dengan indikator tepat waktu adalah 2,93 dan 3,11. Skor ini menunjukkan bahwa secara keseluruhan petani mempunyai persepsi bahwa benih kelapa sawit bersertifikat adalah kurang baik berdasarkan indikator tepat waktu.

b. Tepat Jumlah
Indikator tepat jumlah dibagi menjadi 2 indikator, yaitu jumlah ketersediaan benih dan kesesuaian ketersediaan benih dengan kebutuhan. Total skor indikator jumlah masing-masing kelompok petani pengguna benih bersertifikat dan nonsertifikat adalah 3,87 dan 3,7. Skor ini menunjukkan bahwa indikator tepat jumlah benih kelapa sawit nonsertifikat kedua kelompok petani adalah baik.

c. Tepat Lokasi

ditunjukkan Indikator tepat lokasi kesesuaian dengan kondisi agroekosistem daerah setempat. 
Petani akan menggunakan benih kelapa sawit nonsertifikat bila benih yang digunakan sesuai dengan agroekosistem lahan yang dimiliki oleh petani. Skor yang ditunjukkan oleh petani untuk indikator kesesuaian dengan kondisi agroekosistem lahan petani pengguna benih bersertifikat dan benih nonsertifikat menunjukkan skor 2,04 dn 2,34. Skor yang ditunjukkan oleh kedua kelompok petani menunjukkan bahwa benih kelapa sawit nonsertifikat tidak sesuai atau tidak baik ditanam dilahan mereka. Hal inidapat dilihat melalui hasil yang ditunjukkan oleh bibit yang sudah diaplikasikan di lapangan, banyak tanaman yang pertumbuhannya tidak sesuai dengan umur tanaman, waktu panen yang lebih lama dari 5 tahun, dan bahkan terdapat beberapa petani produktifitas tanaman yang berada di bawah 2 ton/Ha.

d. Tepat Jenis/Varietas Indikator tepat jenis/varietas dianalisis berdasarkan empat atribut, yaitu kesesuaian benih dengan kebutuhan dan kebiasaan petani, kemudahan mendapatkan benih, kemudahan dalam penggunaan/perawatan benih, dan ketahanan terhadap hama dan penyakit tanaman.

Total skor indikator tepat jenis/varietas yang ditunjukkan oleh kedua kelompok petani adalah kurang baik. Masing-masing skor yang dihasilkan oleh kedua kelompok tersebut adalah 2,78 untuk total skor petani pengguna benih bersertifikat dan 2,79 untuk skor petani pengguna benih nonsertifikat. e. Tepat Mutu

Indikator tepat mutu pada penelitian ini dibagi menjadi empat atribut, yaitu daya tumbuh benih, daya simpan benih, produktivitas benih, dan kualitas benih. Petani akan menggunakan benih kelapa sawit nonsertifikat apabila daya tumbuhnya baik, daya simpannya lama, produktivitasnya tinggi, dan kualitasnya baik.

Total skor yang dihasilkan oleh indikator tepat mutu dari kedua kelompok petani adalah 2,03 untuk petani pengguna benih bersertifikat dan 2,73 untuk petani pengguna benih nonsertifikat. Total skor yang dihasilkan menggambarkan bahwa petani pengguna benih bersertifikat mempunyai persepsi bahwa benih kelapa sawit nonsertifikat mempunyai mutu yang tidak baik sementara petani pengguna benih nonsertifikat menggangap benih tersebut kurang baik.

f. Tepat Harga Indikator tepat harga ditentukan berdasarkan harga benih kelapa sawit nonsertifikat. Gambar 2 menunjukkan skor masing-masing kelompok petani kelapa sawit, skor petani kelapa sawit bersertifikat adalah 4,24 dan skor petani nonsertifikat adalah 4,12 . Skor yang dihasilkan menggambarkan bahwa petani pengguna benih bersertifikat mempunyai persepsi bahwa benih kelapa sawit nonsertifikat mempunyai harga yang sangat baik atau murah sementara petani pengguna benih nonsertifikat menggangap benih tersebut mempunyai harga yang murah.

Tabel 3. Persepsi Petani Terhadap Benih Kelapa Sawit Nonsertifikat

\begin{tabular}{llcccc}
\hline No & Variabel & \multicolumn{2}{c}{ Petani Benih Bersertifikat } & \multicolumn{2}{c}{ Petani Benih Nonsertifikat } \\
\cline { 3 - 5 } & & Skor & Kategori & Skor & Kategori \\
\hline 1 & Tepat Waktu & 2,93 & Kurang Baik & 3,11 & Kurang Baik \\
2 & Tepat Jumlah & 3,87 & Baik & 3,7 & Baik \\
3 & Tepat Lokasi & 2,04 & Tidak baik & 2,34 & Tidak baik \\
4 & Tepat Jenis/Varietas & 2,78 & Kurang Baik & 2,79 & Kurang Baik
\end{tabular}




\begin{tabular}{lllccc}
5 & Tepat Mutu & 2,03 & Tidak baik & 2,73 & Kurang Baik \\
6 & Tepat Harga & 4,24 & Sangat Baik & 4,12 & Baik \\
& Total & $\mathbf{2 , 9 8}$ & Kurang Baik & $\mathbf{3 , 1 3}$ & Kurang Baik \\
\hline
\end{tabular}

Tabel 3 menunjukkan bahwa skor rata-rata persepsi petani benih bersertifkat terhadap benih kelapa sawit nonsertifikat adalah 2,98 dan skor rata-rata persepsi petani benih nonsertifikat terhadap benih kelapa sawit nonsertifikat adalah 3,13. Skor rata-rata tersebut menunjukkan bahwa persepsi petani terhadap benih kelapa sawit nonsertifikat tergolong kurang baik. Terdapat beberapa atribut yang menjadi faktor pendorong petani dalam menggunakan benih kelapa sawit nonsertifikat diantaranya : (1) Jumlah benih kelapa sawit nonsertifikat tersedia banyak, (2) Ketersediaan benih sesuai dengan kebutuhan petani, dan (3) Harga benih kelapa sawit nonsertifikat murah. Sementara atribut lain merupakan atribut yang menghambat petani untuk membeli benih kelapa sawit nonsertifikat.

\subsection{Perbandingan Keunggulan Benih Bersertifikat dengan Benih Nonsertifikat}

Tabel 4 menunjukkan nilai rata-rata total persepsi petani terhadap benih kelapa sawit bersertifikat adalah 3,55 dan masuk kedalam kategori baik sedangkan untuk benih kelapa sawit nonsertifikat skor ratarata total persepsi petani ada;ah 2,34 dan termasuk kategori kurang baik. Nilai yang ditunjukkan oleh masing-masing kelompok petani menggambarkan rata-rata total skor benih kelapa sawit bersertifikat lebih tinggi dibandingkan dengan rata-rata total skor benih kelapa sawit nonsertifikat, ini berarti tingkat persepsi petani terhadap benih bersertifikat lebih baik dibandingkan dengan benih nonsertifikat.

Tabel 4. Rata-Rata Total Persepsi PetaniTerhadap Benih Kelapa Sawit

\section{Benih Bersertifikat Benih Nonsertifikat}

\begin{tabular}{cccccc}
\hline No & Variabel & Skor & Kategori & Skor & Kategori \\
\hline 1 & Petani Benih Bersertifikat & 3,59 & Baik & 2,98 & Kurang Baik \\
2 & Petani Benih Nonsertifikat & 3,51 & Baik & 3,13 & Kurang Baik \\
\hline & Rata-Rata Total & $\mathbf{3 , 5 5}$ & Baik & $\mathbf{2 , 3 4}$ & Kurang Baik \\
\hline
\end{tabular}

Pemetaan perbandingan persepsi petani terhadap atribut-atribut yang dimiliki oleh benih kelapa sawit bersertifikat dan nonsertifikat dipetakan dengan menggunakan grafik jaring laba-laba yang dapat dilihat pada Gambar 3. Gambar Tersebut menunjukkan bahwa secara keseluruhan persepsi petani terhadap benih kelapa sawit bersertifikat lebih baik dibandingkan dengan benih kelapa sawit nonsertifikat. a. Tepat Waktu

Terdapat dua indikator dalam menentukan indikator tepat waktu, yaitu ketersediaan benih pada saat dibutuhkan dan umur panen. Perbandingan persepsi petani terhadap benih kelapa sawit bersertifikat dan nonsertifikat dapat dilihat pada Tabel 4. 


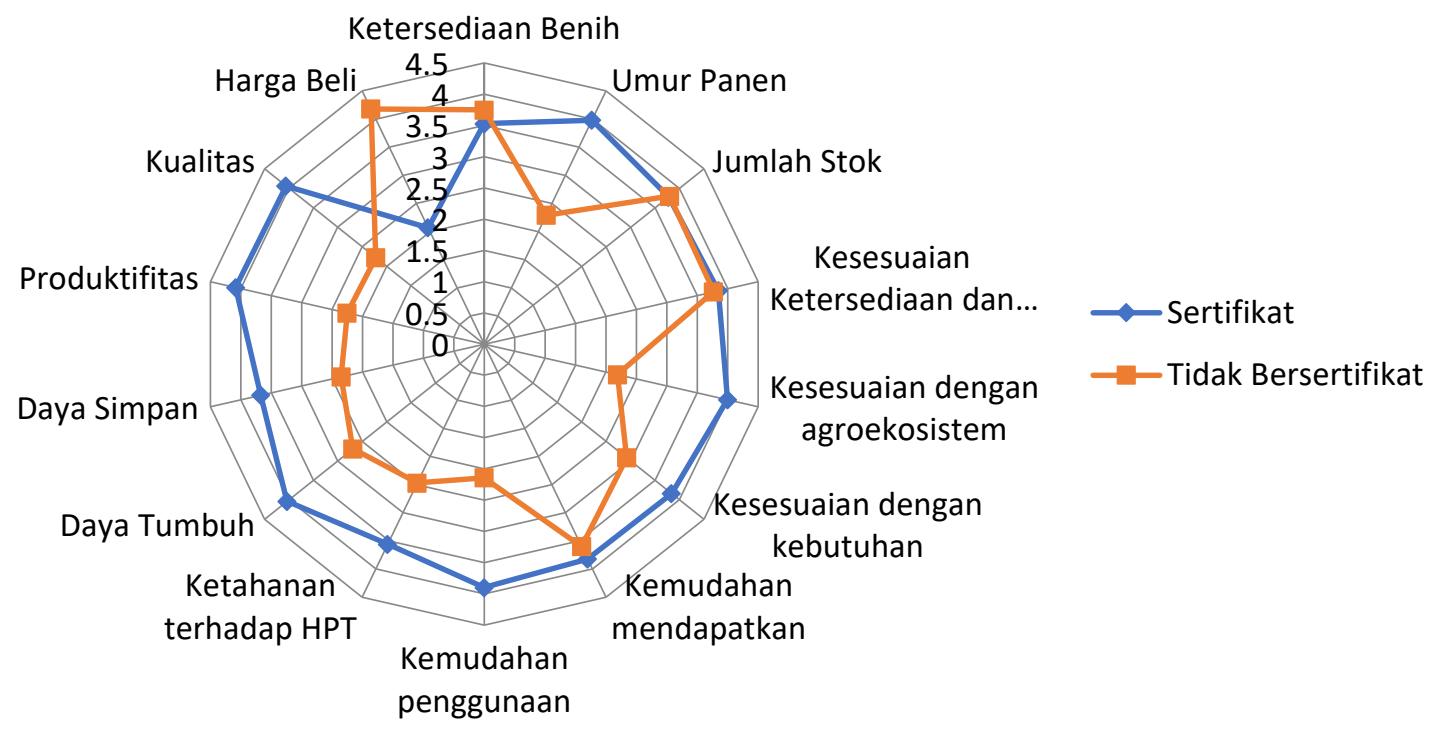

Gambar 3. Peta Persepsi Petani Kelapa Sawit terhadap Benih Bersertifikat dan Nonsertifikat

Atribut umur panen menunjukkan bahwa benih bersertifikat menghasilkan buah pada umur 3-4 tahun sedangkan benih nonsertifikat mulai dipanen di atas umur 4 tahun bahkan terdapat tanaman kelapa sawit yang tidak berbuah hingga usia tanaman 10 tahun. Jaminan kualitas benih yang akan digunakan menyebabkan petani pengguna benih bersertifikat tetap menggunakan benih tersebut walaupun prosedur untuk mendapatkannya lebih sulit jika dibandingkan dengan benih nonsertifikat.

Tabel 4. Perbandingan Persepsi Petani Terhadap Benih Kelapa Sawit Bersertifikat dan Nonsertifikat Berdasarkan Indikator Tepat Waktu

\begin{tabular}{lcll}
\hline No & Atribut & Benih Bersertifikat & \multicolumn{1}{c}{ Benih Nonsertifikat } \\
\hline 1 & $\begin{array}{l}\text { Ketersediaan } \\
\text { Benih }\end{array}$ & $\begin{array}{l}\text { Tersedia (Produsen } \\
\text { Benih Kelapa }\end{array}$ & $\begin{array}{l}\text { Tersedia (perdagangan benih antar } \\
\text { petani) }\end{array}$ \\
2 & Umur Panen & $\begin{array}{l}\text { Sawit,kelompok tani) } \\
\text { Cepat (3-4 tahun } \\
\text { setelah tanam) }\end{array}$ & $\begin{array}{l}\text { Lebih lama (di atas 4 tahun bahkan tidak } \\
\text { berbuah sampai umur tanaman 10 } \\
\text { tahun) }\end{array}$ \\
\hline
\end{tabular}

b. Tepat Jumlah

Indikator tepat jumlah dibagi menjadi 2 atribut, yaitu jumlah ketersediaan benih dan kesesuaian ketersediaan benih dengan kebutuhan. Perbandingan antara benih kelapa sawit bersertifikat dengan benih nonsertifikat berdasarkan persepsi petani dapat dilihat pada Tabel 12 . Ketersediaan benih bersertifikat berdasarkan persepsi petani terbatas sedangkan benih nonsertifikat tersedia banyak di lapangan berdasarkan persepsi petani dan bisa didapatkan kapan saja dibutuhkan. Sedangkan kesesuaian 
ketersediaan benih dengan kebutuhan petani dapat dikategorikan baik. Jumlah benih yang mereka perlukan sesuai dengan jumlah yang dibutuhkan hanya saja bagi petani benih nonsertifikat, benih yang dibutuhkan lebih banyak karena membutuhkan penyisipan yang lebih banyak jika dibandingkan dengan benih bersertifikat.

Tabel 5. Perbandingan Benih Kelapa Sawit Bersertifikat dan Nonsertifikat Berdasarkan Persepsi Petani terhadap Indikator Tepat Jumlah

\begin{tabular}{llll}
\hline No & Atribut & Benih Bersertifikat & Benih Nonsertifikat \\
\hline 1 & Ketersediaan Benih & Terbatas & Cukup Banyak \\
2 & Kesesuaian Ketersediaan & 150 buah/Ha & $190 \mathrm{Buah} / \mathrm{Ha}$ \\
& Benih dengan Kebutuhan & & \\
\hline
\end{tabular}

c. Tepat Lokasi

Indikator tepat lokasi ditunjukkan berdasarkan kesesuaian dengan kondisi agroekosistem daerah setempat. Perbandingan benih kelapa sawit bersertifikat dan nonsertifikat berdasarkan persepsi petani terhadap indikator tepat lokasi dapat dilihat pada Tabel 6 . Berdasarkan tabel dapat dilihat bahwa berdasarkan indikator tepat lokasi benih bersertifikat lebih sesuai ditanam di Kabupaten Labuhan Batu Utara dibandingkan dengan benih kelapa sawit nonsertifikat.

Tabel 6. Perbandingan Benih Kelapa Sawit Bersertifikat dan Nonsertifikat Berdasarkan Persepsi Petani Terhadap Indikator Tepat Lokasi

\begin{tabular}{llll}
\hline No & Atribut & Benih Bersertifikat & Benih Nonsertifikat \\
\hline 1 & Kesesuian & Sesuai dengan agroekosistem & Kurang sesuai dengan \\
& dengan & Kabupaten Labuhan Batu Utara & $\begin{array}{l}\text { agroekosistem } \\
\text { Agroekosistem }\end{array}$ \\
& & $\begin{array}{l}\text { Kabupaten Labuhan } \\
\text { Batu Utara }\end{array}$ \\
\hline
\end{tabular}

d. Tepat Jenis/Varietas

Indikator tepat jenis/varietas dianalisis berdasarkan empat jenis atribut, yaitu kesesuaian benih dengan kebutuhan dan kebiasaan petani, kemudahan mendapatkan benih, kemudahan dalam penggunaan/perawatan benih, dan ketahanan terhadap hama dan penyakit tanaman.

Tabel 7. Perbandingan Benih Kelapa Sawit Bersertifikat dan Nonsertifikat Berdasarkan Persepsi Petani Terhadap Indikator Tepat Jenis/Varietas

\begin{tabular}{llcc}
\hline No & Atribut & Benih Bersertifikat & Benih Nonsertifikat \\
\hline & Kesesuaian dengan Kebiasaan & Sudah Terbiasa & Belum Terbiasa \\
1 & Petani & Mudah & Mudah \\
2 & Kemudahan Mendapatkan Benih & Mudah & Tidak Mudah \\
3 & Kemudahan Penggunaan Benih & Tahan & Kurang Tahan \\
4 & Ketahanan Terhadap HPT & \\
\hline
\end{tabular}

e. Tepat Mutu

Indikator tepat mutu pada penelitian ini dibagi menjadi empat atribut, yaitu daya tumbuh benih, daya simpan benih, produktivitas benih, dan kualitas benih.
Tabel 8 menggambarkan perbandingan persepsi petani berdasarkan indikator tepat mutu antara benih kelapa sawit bersertifikat dengan benih nonsertifikat. Berdasarkan atribut daya tumbuh benih, 
benih bersertifikat lebih baik dibandingkan dengan benih nonsertifikat. $\mathrm{Hal}$ ini ditunjukkan dengan pertumbuhan benih yang merata pada saat diaplikasi di lapangan sementara padabenih nonsertifikat, pertumbuhan benihnya tidak seragam. Atribut daya simpan benih berrsertifikat lebih baik jika dibandingkan dengan benih kelapa sawit nonsertifikat. Persepsi petani terhadap benih kelapa sawit bersertifikat dinilai sangat baik dari atribut kualitas benih jika dibandingkan dengan benih kelapa sawit nonsertifikat.

Tabel 8. Perbandingan Benih Kelapa Sawit Bersertifikat dan Nonsertifikat Berdasarkan Persepsi Petani Terhadap Indikator Tepat Mutu

\begin{tabular}{clcc}
\hline No & Atribut & Benih Bersertifikat & Benih Nonsertifikat \\
\hline 1 & Daya Tumbuh Benih & Baik & Kurang Baik \\
2 & Daya Simpan Benih & Cukup Lama & Tidak Lama \\
3 & Produktifitas & 3,4 Ton/Ha & 1,2 ton/Ha \\
4 & Kualitas Benih & Sangat Baik & Kurang Baik \\
\hline
\end{tabular}

f. Tepat Harga

Indikator tepat harga ditentukan berdasarkan harga benih kelapa sawit bersertifikat. Harga mahal yang ditawarkan oleh benih kelapa sawit bersertifikat sesuai dengan hasil yang didapat oleh petani sehingga petani tidak merasa dirugikan dengan harga yang ditawarkan. Kesadaran petani pengguna benih bersertifikat akan pentingnya investasi awal pada pembenihan/pembibitan sudah cukup tinggi karena mereka paham bahwa bibit/benih merupakan monumental, yang berarti kesalahan dalam memilih benih kelapa sawit akan merugikan petani selama umur tanaman ( \pm 25 tahun).

\section{Kesimpulan}

Skor rata-rata persepsi petani benih bersertifkat terhadap benih kelapa sawit bersertifikat adalah 3,59 dan skor rata-rata persepsi petani benih nonsertifikat terhadap benih kelapa sawit bersertifikat adalah 3,51. Skor rata-rata tersebut menunjukkan bahwa persepsi petani terhadap benih kelapa sawit bersertifikat tergolong baik. Walaupun terdapat beberapa atribut yang menjadi faktor penghambat petani dalam menggunakan benih kelapa sawit bersertifikat diantaranya : (1) Faktor penghambat pengunaaan benih kelapa sawit bersertifikat oleh petani benih bersertifikat adalah atribut harga yang tergolong mahal bagi petani dan (2) Faktor penghambat penggunaan benih kelapa sawit bersertifikat oleh petani benih nonsertifikat adalah ketersediaan benih dan harga yang tergolong mahal bagi petani.

\section{Daftar Pustaka}

Direktorat Jendral Perkebunan.2015. Statistik Perkebunan Indonesia. Jakarta. Kementerian Pertanian

Emiria, F. dan H. Purwandari. 2014. Pengembangan pertanian organik di Kelompok Tani Madya, Desa Kebonagung, Kabupaten Bantul, Daerah Istimewa Yogyakarta. Jurnal Penyuluhan 10 (2).

Engel, James F, R.D Blackweel, P.J. Winiard. $1995 . \quad$ Perilaku Konsumen, Jilid 1.Jakarta: Bina Rupa aksara.

Joni, M.M.A, M.F.R. Rubzen, and P.J.Batt. 2001. Factors influencing a farmer's decision to purchase seed potatoes in East Java. Paper presented at the 45th Annual Conference of the Australian Agricultural and Resource Economics Society, Adelaide, South Australia.

Kotler, P. dan Kevin Lane Keller. 2007. Manajemen Pemasaran Edisi 12. Jakarta: Indeks.

Kotler, P. dan Garry Amstrong. 2016. Principles of Marketing. Pearson Education. England.

Sumarwan, U. 2010. Perilaku Konsumen. PT Ghalia Indonesia, Anggota IKAPI, 
Agriprimatech

Vol. 4 No. 2, April 2021

e-ISSN : 2621-6566

Bogor. 